\title{
The Analysis on the Differences and Influencing Factors of DEA Business Efficiency of Rural Credit Cooperatives
}

\author{
WANG Chongrun \\ School of Finance \\ Hebei University of Economics and Business \\ Shijiazhuang, 050061, China \\ wchongrun@heuet.edu.cn
}

\author{
WEN Kai \\ School of Finance \\ Hebei University of Economics and Business \\ Shijiazhuang, 050061, China
}

\begin{abstract}
This paper explored changes in the business efficiency of Rural Credit Cooperatives (RCCs)in eleven regions of Hebei province since the rural finance reform beginning in 2003. We measured the business efficiency by using DEA-BCC Model and Malmquist index. On the whole DEA efficiency showed improvement while each region's RCCs DEA efficiency existing obvious differences over the 2004 2015 period. Malmquist analysis showed financial service technique innovation became the major cause of DEA efficiency enhancement since year 2010. Tobit regression showed that internal factors like credit scale, risks controlling and financial innovation, which reflect scale efficiency and pure technical efficiency, and environmental variables like per capita disposable income and agricultural GDP proportion, had significant effects on DEA efficiency. This paper is the first to make comparative study on the business efficiency of RCCs in eleven regions of Hebei province.
\end{abstract}

Keywords-Rural Credit Cooperatives(RCCs), Business efficiency, DEA-TOBIT, Malmquist index

\section{INTRODUCTION}

Since 2003, domestic scholars have used DEA method to analyze the efficiency of commercial banks (YUAN Yunfeng, 2006)[1], which is divided into three cases. First, the traditional DEA and super-efficiency model are used to analyze the comprehensive efficiency of financial institutions and decompose into technical efficiency and scale efficiency (ZHENG Guiting and QI Shutian, 2006[2]; ZHAO Xiang, 2010[3]; LI Mingdi, 2015[4]). The second is the combination of DEA and Malmquist model evaluating the business efficiency from the static and dynamic point of view. (XU Zhong, 2006[5])Thirdly, combining DEA with Tobit model. Tobit regression analysis was carried out to analyze the influencing factors of DEA. Most literatures suggested that the overall efficiency of Rural Credit Cooperatives (RCCs)is improved after the reform however is still ineffective. The main reason is the low efficiency of pure technology (LAN Hong, 2014[6]; WANG Xiaoning, 2016[7], WU Shaoxin, 2009[8]).

When the DEA method is used to measure the efficiency of the banks, the biggest problem is that there are big

Sponsored by Hebei province humanities and social science research major project (No. ZD201415); Hebei province social science fund project (No. HB13GL031); Hebei province soft science project (No. 15457665D) differences in the choice of the efficiency indexes, which leads to the unreliability and instability in result to some extent. This is the problem that needs to be overcome in this research. The choice of the indexes must be based on an objective understanding of the positioning and role of RCCs. In addition, the early literatures were limited to the number of samples, the empirical analysis results were not stable, particularly could not effectively analyze the changes in efficiency. This paper is based on the financial data of 11 cities' RCCs from 2005 to 2014 and so the observation period is much longer, the sample size is relatively large, and the regression analysis results will be more accurate. This is the two advances of this paper.

\section{INDEX SELECTION AND DATA SOURCES}

\section{A. Index selection}

In recent years, the DEA method has become one of the mainstream ways to study the operational efficiency of financial institutions. The traditional DEA model includes the CCR and BBC models, where the CCR model is the first basic model and is based on constant returns to scale. The BBC extends the condition to variable returns to scale. The economies of scale of the banking industry are obvious. So BBC model is used to analyze.

Combining the available data and existing literature, the indicators we selected included four input indicators and two output indicators and one non-expected output indicator

Input indicators include: (1) Net fixed assets, which is the basis for the provision of services and continuing operations. (2) Labor cost, which refers to the wages and benefits of labor and training costs, reflects the RCCs of human capital investment. (3) Operating expenses (except staff expenses), a measure of the material capital investment of the RCCs in carrying out their business activities.(4) Overall deposits, which reflects the market share of RCCs, is the main source of loans and investment.

Output indicators include: (1) Net interest income, which is the main source of income of RCCs to measure the traditional deposit and loan business operations. (2) Noninterest income, reflecting the RCCs intermediary business, emerging business and other innovative business situations. 


\section{AThNIIS PRESS}

Unexpected output indicators: risk is an unavoidable problem for financial institutions. The current rate of nonperforming assets of RCCs is too high. If the quality of loans is neglected, it will virtually expand its actual efficiency. In order to solve this problem, this paper regards nonperforming loan rate as an unexpected output indicator. It is noted that negative output should be avoided in the operation of DEAP2.1, for different from interest income and non-interest income, non-performing loan rate is a negative output. Risk output of agricultural credit cooperatives is measured by nonperforming loans with its reciprocal, as an indicator of non-expected output.

\section{B. Data Sources}

The data of the RCCs of 11 cities in Hebei Province are derived from the annual financial statements of Hebei Province RCCs from 2005-2014, and regional economic data from the 2005-2010 "Hebei Province Statistical Yearbook". Part of the data is calculated by the author based on the sample data.

\section{EMPIRICAL RESULTS AND DISCUSSION ON MANAGEMENT EFFICIENCY OF RCCS}

\section{A. Efficiency Analysis Based on BBC Model}

TABLE I. EFFICIENCY VALUES OF 11 CITIES’ RCCS FROM YEAR 2005 - 2014

\begin{tabular}{|c|c|c|c|c|c|c|c|c|c|c|c|c|c|c|c|c|c|c|c|c|c|}
\hline & \multicolumn{3}{|c|}{2005} & \multicolumn{3}{|c|}{2006} & \multicolumn{3}{|c|}{2007} & \multicolumn{3}{|c|}{2008} & \multicolumn{3}{|c|}{2009} & \multicolumn{3}{|c|}{2010} & \multicolumn{3}{|c|}{2011} \\
\hline RCC & crste & vrste & scale & crste & vrste & scale & crste & vrste & scale & crste & vrste & scale & crste & vrste & scale & crste & vrste & scale & crste & vrste & scale \\
\hline Baoding & 0.518 & 0.716 & 0.722 & 0.968 & 0.968 & 1 & 0.547 & 0.572 & 0.956 & 0.4 & 0.478 & 0.838 & 0.466 & 0.527 & 0.884 & 0.863 & 1 & 0.863 & 0.948 & 1 & 0.948 \\
\hline Cangzhou & 0.45 & 0.562 & 0.801 & 1 & 1 & 1 & 0.442 & 0.581 & 0.761 & 0.505 & 0.674 & 0.75 & 0.511 & 0.609 & 0.839 & 0.969 & 0.98 & 0.988 & 0.922 & 0.936 & 0.985 \\
\hline Chengde & 1 & 1 & 1 & 1 & 1 & 1 & 1 & 1 & 1 & 1 & 1 & 1 & 1 & 1 & 1 & 1 & 1 & 1 & 1 & 1 & 1 \\
\hline Handan & 0.664 & 1 & 0.664 & 1 & 1 & 1 & 0.837 & 0.935 & 0.895 & 0.956 & 1 & 0.956 & 0.831 & 0.848 & 0.98 & 0.827 & 0.833 & 0.993 & 1 & 1 & 1 \\
\hline Hengshui & 0.404 & 0.656 & 0.616 & 0.732 & 1 & 0.732 & 0.478 & 0.643 & 0.743 & 0.51 & 0.692 & 0.737 & 0.426 & 0.625 & 0.682 & 1 & 1 & 1 & 1 & 1 & 1 \\
\hline Langfang & 0.712 & 0.88 & 0.809 & 1 & 1 & 1 & 1 & 1 & 1 & 1 & 1 & 1 & 0.854 & 0.866 & 0.987 & 1 & 1 & 1 & 1 & 1 & 1 \\
\hline Qinhuangd & 0.525 & 1 & 0.525 & 0.686 & 1 & 0.686 & 1 & 1 & 1 & 1 & 1 & 1 & 1 & 1 & 1 & 1 & 1 & 1 & 1 & 1 & 1 \\
\hline Shijiazhua & 0.51 & 0.551 & 0.925 & 1 & 1 & 1 & 0.763 & 0.789 & 0.967 & 0.542 & 0.572 & 0.948 & 0.519 & 0.546 & 0.95 & 1 & 1 & 1 & 1 & 1 & 1 \\
\hline Tangshan & 1 & 1 & 1 & 1 & 1 & 1 & 1 & 1 & 1 & 1 & 1 & 1 & 1 & 1 & 1 & 1 & 1 & 1 & 1 & 1 & 1 \\
\hline Xingtai & 0.42 & 0.672 & 0.626 & 0.526 & 0.817 & 0.644 & 0.450 & 0.739 & 0.609 & 0.356 & 0.715 & 0.499 & 0.434 & 0.717 & 0.606 & 0.996 & 1 & 0.996 & 0.826 & 0.832 & 0.992 \\
\hline Zhangjiako & 1 & 1 & 1 & 1 & 1 & 1 & 1 & 1 & 1 & 1 & 1 & 1 & 1 & 1 & 1 & 0.963 & 1 & 0.963 & 0.933 & 0.94 & 0.992 \\
\hline mean & 0.655 & 0.822 & 0.79 & 0.901 & 0.98 & 0.915 & 0.774 & 0.842 & 0.903 & 0.752 & 0.83 & 0.884 & 0.731 & 0.794 & 0.903 & 0.965 & 0.983 & 0.982 & 0.966 & 0.974 & 0.993 \\
\hline
\end{tabular}

CONNECTING TO TABLE I

\begin{tabular}{|l|l|l|l|l|l|l|l|l|l|}
\hline & \multicolumn{3}{|c|}{$\mathbf{2 0 1 2}$} & \multicolumn{3}{c|}{$\mathbf{2 0 1 3}$} & \multicolumn{3}{|c|}{$\mathbf{2 0 1 4}$} \\
\hline \multicolumn{1}{|c|}{ RCC } & crste & vrste & scale & crste & vrste & scale & crste & vrste & scale \\
\hline Baoding & 1 & 1 & 1 & 1 & 1 & 1 & 1 & 1 & 1 \\
\hline Cangzhou & 1 & 1 & 1 & 1 & 1 & 1 & 0.972 & 0.977 & 0.995 \\
\hline Chengde & 1 & 1 & 1 & 1 & 1 & 1 & 1 & 1 & 1 \\
\hline Handan & 0.945 & 1 & 0.945 & 1 & 1 & 1 & 1 & 1 & 1 \\
\hline Hengshui & 1 & 1 & 1 & 0.924 & 0.934 & 0.99 & 1 & 1 & 1 \\
\hline Langfang & 1 & 1 & 1 & 1 & 1 & 1 & 1 & 1 & 1 \\
\hline Qinhuangd & 1 & 1 & 1 & 1 & 1 & 1 & 1 & 1 & 1 \\
\hline Shijiazhua & 0.959 & 0.985 & 0.974 & 0.911 & 0.931 & 0.978 & 1 & 1 & 1 \\
\hline Tangshan & 1 & 1 & 1 & 1 & 1 & 1 & 0.8071 & 0.826 & 0.976 \\
\hline Xingtai & 0.87 & 0.899 & 0.968 & 0.824 & 0.833 & 0.989 & 1 & 1 & 1 \\
\hline Zhangjiako & 0.869 & 0.921 & 0.944 & 0.86 & 0.934 & 0.921 & 0.785 & 0.811 & 0.968 \\
\hline mean & 0.968 & 0.982 & 0.985 & 0.956 & 0.967 & 0.989 & 0.817 & 0.940 & 0.869 \\
\hline
\end{tabular}

As can be seen from TABLE I, since 2005 the reform of RCCs, the average comprehensive efficiency of RCCs is on the rise. Among them, 2007 - 2009 during a certain decline, the reason why the operating efficiency of a certain decline during 2007 to 2009 is US financial crisis in 2008, the economic growth trend slowed down, many small and medium enterprises operating difficulties, the financial industry has been a strong impact. After the financial crisis, the overall efficiency has been restored and improved, fluctuating at 0.95 .
It is worth noting that efficiency is still lagging behind in terms of efficiency. For example, the overall efficiency in 2014 is 0.944 , indicating that $94.4 \%$ of existing resources are available to achieve the current level of output, while the remaining $5.6 \%$ of the inputs are wasted.

It is noteworthy that the average comprehensive efficiency of RCCs is 0.868 , the average pure technical efficiency and scale efficiency are 0.913 and 0.943 respectively, which means that $60.4 \%$ of efficiency loss is due to ineffective pure technology, $39.6 \%$ is due to scale efficiency loss, Low technical efficiency is an important reason for the low efficiency of RCCs. The improvement of pure technical efficiency after 2010 is the main reason for the improvement of operating efficiency in this period. The improvement of pure technical efficiency reflects the continuous strengthening of technological innovation and investment in information system since 2010, which has enabled the improvement of pure technical efficiency.

By calculating the standard deviation of pure technical efficiency from 2005 to 2014, it can reflect the gap between the operation of RCCs. Prior to 2010 (except 2006), the standard deviation of pure technical efficiency fluctuated at 0.2 level. From 2010 to 2014, the standard deviation of local cities fell to 0.04, which indicated that the gap between the technical efficiency of RCCs was stable. During this period, the management technology of each RCCs develops more comprehensive and regional differences became narrow. 


\section{B. Malmquist Dynamic Efficiency Analysis}

It is not enough only to study the efficiency of RCCs from static point. We also need to analyze the reasons of efficiency change. The Malmquist index method can be used not only to specify the efficiency dynamic change but also to analyze the inefficiency causes through the technical efficiency index and the technology progress index.

This paper uses the software Deap2.1 to establish the Malmquist index model. The results are shown in TABLE II.

TABLE II. TOTAL FACTOR PRODUCTIVITY (TFP) OF RCCS FROM YEAR 2005 TO 2014

\begin{tabular}{|c|c|c|c|c|c|}
\hline Year & $\begin{array}{l}\text { Technical } \\
\text { Efficiency } \\
\text { Change } \\
\text { Index } \\
\text { (EFFC) }\end{array}$ & $\begin{array}{l}\text { Technology } \\
\text { Progress } \\
\text { Index (TC) }\end{array}$ & $\begin{array}{l}\text { Pure } \\
\text { Technology } \\
\text { Efficiency } \\
\text { Change } \\
\text { Index (PEC) }\end{array}$ & $\begin{array}{l}\text { Scale } \\
\text { efficiency } \\
\text { change } \\
\text { index } \\
\text { (SEC) }\end{array}$ & $\begin{array}{l}\text { Total Factor } \\
\text { Productivity } \\
\text { Change Index } \\
\text { (TFP) }\end{array}$ \\
\hline $\begin{array}{c}2005- \\
2006\end{array}$ & 1.430 & 0.694 & 1.223 & 1.169 & 0.992 \\
\hline $\begin{array}{c}2006- \\
2007\end{array}$ & 0.831 & 0.867 & 0.840 & 0.988 & 0.720 \\
\hline $\begin{array}{c}2007- \\
2008\end{array}$ & 0.951 & 0.777 & 0.978 & 0.972 & 0.739 \\
\hline $\begin{array}{c}2008- \\
2009\end{array}$ & 0.986 & 0.905 & 0.959 & 1.027 & 0.892 \\
\hline $\begin{array}{c}2009- \\
2010\end{array}$ & 1.401 & 0.824 & 1.273 & 1.101 & 1.155 \\
\hline $\begin{array}{c}2010- \\
2011\end{array}$ & 1.001 & 1.136 & 0.990 & 1.011 & 1.138 \\
\hline $\begin{array}{c}2011- \\
2012\end{array}$ & 1.002 & 0.970 & 1.01 & 0.992 & 0.971 \\
\hline $\begin{array}{c}2012- \\
2013\end{array}$ & 0.987 & 1.016 & 0.983 & 1.004 & 1.004 \\
\hline $\begin{array}{c}2013- \\
2014\end{array}$ & 0.985 & 1.071 & 0.991 & 0.993 & 1.055 \\
\hline mean & 1.048 & 0.908 & 1.020 & 1.027 & 0.951 \\
\hline
\end{tabular}

It can be seen from TABLE II that the total factor productivity (TFP) of the RCCs remained stable in the period from 2005 to 2014. The Malmquist index was 0.951, according to the Malmquist productivity index indicating that throughout the whole observation period, the average efficiency is reduced by $4.9 \%$. Indicators were significantly reduced due to the financial crisis in 2008.Nevertheless, from the annual average, total factor labor productivity maintains at a very good level. Further, TFP is decomposed, from the perspective of efficiency growth structure, technical progress index (TC) value is less than 1 , an average decline of $9.2 \%$, but the technical efficiency change index (EFFC) is greater than 1 , the average growth rate of $4.8 \%$. The two together determine the Malmquist productivity index. The scale efficiency change index (SEC) was significantly increased by
$2.7 \%$ and the pure technical efficiency change index (PEC) increased by an average of $2 \%$ on the basis of decomposition of EFFC. The two jointly decided EFFC change. So in 2005 and 2014, the average improvement in technical efficiency has a greater impact on the TFP. However, in the vertical direction, during the period of 2011-2014, the technological progress index increased from 0.97 to 1.071 , while the technical efficiency change index decreased from 1.002 to 0.985 . It indicates that the improvement of TFP in recent years is mainly due to technological progress and technological innovation. With the continuous progress of modern science and technology, Hebei Province increase investment in RCCs, relying on modern payment systems, mobile ATM machines, online banking and other new technology channels rapid development.

TABLE III. 11 CITIES’ RCCS DYNAMIC EFFICIENCY FROM 2005 - 2014

\begin{tabular}{|c|l|l|l|l|l|}
\hline City RCC & \multicolumn{1}{|c|}{ EFFC } & \multicolumn{1}{|c|}{ TC } & \multicolumn{1}{|c|}{ PEC } & \multicolumn{1}{|c|}{ SEC } & \multicolumn{1}{|c|}{ TFP } \\
\hline Baoding & 1.076 & 0.907 & 1.038 & 1.037 & 0.976 \\
\hline Cangzhou & 1.089 & 0.912 & 1.063 & 1.024 & 0.993 \\
\hline Chengde & 1 & 0.774 & 1 & 1 & 0.774 \\
\hline Handan & 1.047 & 0.929 & 1 & 1.047 & 0.972 \\
\hline Hengshui & 1.106 & 0.861 & 1.048 & 1.055 & 0.952 \\
\hline Langfang & 1.038 & 1.014 & 1.014 & 1.024 & 1.053 \\
\hline Qinhuangdao & 1.074 & 0.848 & 1 & 1.074 & 0.911 \\
\hline Shijiazhuang & 1.052 & 0.924 & 1.046 & 1.006 & 0.973 \\
\hline Tangshan & 1 & 0.956 & 1 & 1 & 0.956 \\
\hline Xingtai & 1.072 & 0.927 & 1.021 & 1.05 & 0.993 \\
\hline Zhangjiakou & 0.978 & 0.955 & 0.993 & 0.985 & 0.934 \\
\hline mean & 1.048 & 0.908 & 1.02 & 1.027 & 0.951 \\
\hline
\end{tabular}

In terms of sub-city, the TFP of Langfang is the best, with an average increase of 5.3\%. The efficiency of other RCCs has decreased during the observation period. The largest decrease in Chengde City is $22.6 \%$.Technical progress is relatively slow tired. It shows that the development speed of science and technology innovation in Chengde City is relatively lagging behind its ability to operate and service, and the production boundary moves to the origin. And Zhangjiakou City is the only provinces of the index are less than 1 of the city. Zhangjiakou RCCs technical efficiency is low, returns to scale were declining. Malmquist dynamic efficiency analysis results well explain the reasons for the change in the efficiency of RCCs in Zhangcheng region.

\section{INFLUENCING FACTORS OF EFFICIENCY OF RCCS}

\section{A. Index selection}

According to the analysis of the factors affecting the efficiency of RCCs, we establish the Tobit regression model with the deposit and loan ratio, non-interest income, liquidity ratio, provision coverage rate / non-performing loan ratio, 
proportion of agriculture-related loans, per capita disposable income, and Total agricultural output ratio as the independent variable and the DEA efficiency as the dependent variable.

$$
y_{i}=\beta_{0}+\beta_{1} x_{1 i}+\beta_{2} X_{2 i}+\beta_{3} X_{3 i}+\beta_{4} X_{4 i}+\beta_{5} x_{5 i}+\beta_{6} x_{6 i}+\beta_{7} x_{7 i}+\varepsilon_{i}, i=1,2 \ldots n
$$

$x_{1} \sim x_{7}$ are the variables of the influencing factors both inside and outside, $\beta_{0}$ is the constant term, $\beta_{1} \sim \beta_{7}$ is the regression coefficient of each independent variable, and $\varepsilon_{i}$ is random error.

B. Regression results and analysis

TABLE IV. RCCS EFFICIENCY IMPACT FACTORS REGRESSION ANALYSIS

\begin{tabular}{|c|c|c|c|c|c|c|c|}
\hline Coefficient & $\begin{array}{c}\text { Deposit } \\
\text { to } \\
\text { loan } \\
\text { ratio }\end{array}$ & $\begin{array}{l}\text { Non-interest income to } \\
\text { interest income ratio }\end{array}$ & $\begin{array}{l}\text { Liquidity } \\
\text { ratio }\end{array}$ & $\begin{array}{c}\text { Provision coverage/ } \\
\text { nonperforming loan ratio }\end{array}$ & $\begin{array}{c}\text { Proportion of agriculture } \\
\text { - related loans }\end{array}$ & $\begin{array}{l}\text { Proportion of } \\
\text { agricultural output }\end{array}$ & $\begin{array}{l}\text { Per capita } \\
\text { disposable } \\
\text { income }\end{array}$ \\
\hline Baoding & $\begin{array}{l}3.3419 \\
(0.1019)\end{array}$ & $\begin{array}{l}2.5771 \\
(0.0000)\end{array}$ & $\begin{array}{c}0.5566 \\
(0.4162)\end{array}$ & $\begin{array}{c}0.3830 \\
(0.0000)\end{array}$ & $\begin{array}{l}-0.0680 \\
(0.6020)\end{array}$ & $\begin{array}{l}-11.3265 \\
(0.0000)\end{array}$ & $\begin{array}{c}0.1141 \\
(0.5901)\end{array}$ \\
\hline Cangzhou & $\begin{array}{c}0.4056 \\
(0.2182)\end{array}$ & $\begin{array}{l}1.8534 \\
(0.4053)\end{array}$ & $\begin{array}{c}0.2876 \\
(0.0616)\end{array}$ & $\begin{array}{l}1.0994 \\
(0.0476)\end{array}$ & $\begin{array}{l}-0.0831 \\
(0.8100)\end{array}$ & $\begin{array}{c}8.2726 \\
(0.0000)\end{array}$ & $\begin{array}{c}0.1993 \\
(0.0006)\end{array}$ \\
\hline Chengde & $\begin{array}{c}2.4941 \\
(0.0000)\end{array}$ & $\begin{array}{c}0.9575 \\
(0.2231)\end{array}$ & $\begin{array}{c}0.3962 \\
(0.0000)\end{array}$ & $\begin{array}{c}0.3679 \\
(0.5228)\end{array}$ & $\begin{array}{c}0.0536 \\
(0.4131)\end{array}$ & $\begin{array}{l}-1.7671 \\
(0.0000)\end{array}$ & $\begin{array}{c}0.4105 \\
(0.0000)\end{array}$ \\
\hline Handan & $\begin{array}{c}1.2862 \\
(0.0000)\end{array}$ & $\begin{array}{l}1.3484 \\
(0.5215)\end{array}$ & $\begin{array}{l}0.1105 \\
(0.0000)\end{array}$ & $\begin{array}{c}0.8066 \\
(0.2464)\end{array}$ & $\begin{array}{c}0.0012 \\
(0.3165)\end{array}$ & $\begin{array}{l}-1.9879 \\
(0.0000)\end{array}$ & $\begin{array}{c}0.1413 \\
(0.0000)\end{array}$ \\
\hline Hengshui & $\begin{array}{c}3.8866 \\
(0.0000)\end{array}$ & $\begin{array}{l}-0.1167 \\
(0.9084)\end{array}$ & $\begin{array}{c}1.1124 \\
(0.0002)\end{array}$ & $\begin{array}{l}0.7763 \\
(0.396)\end{array}$ & $\begin{array}{c}0.1896 \\
(0.0000)\end{array}$ & $\begin{array}{c}1.5260 \\
(0.4786)\end{array}$ & $\begin{array}{c}0.3351 \\
(0.1416)\end{array}$ \\
\hline Langfang & $\begin{array}{c}0.5605 \\
(0.5054)\end{array}$ & $\begin{array}{c}-0.0424 \\
(0.9790)\end{array}$ & $\begin{array}{c}0.6069 \\
(0.4769)\end{array}$ & $\begin{array}{c}0.6705 \\
(0.1980)\end{array}$ & $\begin{array}{c}0.1946 \\
(0.2944)\end{array}$ & $\begin{array}{c}-0.8384 \\
(0.9468)\end{array}$ & $\begin{array}{c}0.0435 \\
(0.8801)\end{array}$ \\
\hline Qinhuangdao & $\begin{array}{c}0.9055 \\
(0.0259)\end{array}$ & $\begin{array}{c}0.4623 \\
(0.3920)\end{array}$ & $\begin{array}{c}1.1482 \\
(0.0664)\end{array}$ & $\begin{array}{c}0.6185 \\
(0.0051)\end{array}$ & $\begin{array}{c}0.0090 \\
(0.5445)\end{array}$ & $\begin{array}{l}-4.3046 \\
(0.3738)\end{array}$ & $\begin{array}{c}0.1429 \\
(0.0040)\end{array}$ \\
\hline Shijiazhuang & $\begin{array}{c}1.1187 \\
(0.0000)\end{array}$ & $\begin{array}{c}0.6847 \\
(0.0000)\end{array}$ & $\begin{array}{c}0.4338 \\
(0.0000)\end{array}$ & $\begin{array}{c}1.6995 \\
(0.0000)\end{array}$ & $\begin{array}{c}0.0117 \\
(0.5242)\end{array}$ & $\begin{array}{l}-5.5181 \\
(0.0000)\end{array}$ & $\begin{array}{c}0.3078 \\
(0.0000)\end{array}$ \\
\hline Tangshan & $\begin{array}{c}0.4378 \\
(0.0951)\end{array}$ & $\begin{array}{l}-1.8183 \\
(0.0000)\end{array}$ & $\begin{array}{c}0.0509 \\
(0.6298)\end{array}$ & $\begin{array}{c}0.8335 \\
(0.0000)\end{array}$ & $\begin{array}{c}1.3248 \\
(0.0000)\end{array}$ & $\begin{array}{l}-6.7787 \\
(0.0000)\end{array}$ & $\begin{array}{c}0.0494 \\
(0.0000)\end{array}$ \\
\hline Xingtai & $\begin{array}{c}8.1603 \\
(0.0000)\end{array}$ & $\begin{array}{c}0.1412 \\
(0.3188)\end{array}$ & $\begin{array}{c}0.4038 \\
(0.0000)\end{array}$ & $\begin{array}{c}0.3241 \\
(0.0000)\end{array}$ & $\begin{array}{l}0.1632 \\
(0.000)\end{array}$ & $\begin{array}{c}-45.5376 \\
(0.0000)\end{array}$ & $\begin{array}{c}1.2044 \\
(0.0000)\end{array}$ \\
\hline Zhangjiakou & $\begin{array}{c}0.5378 \\
(0.0506)\end{array}$ & $\begin{array}{c}-0.0329 \\
(0.9677)\end{array}$ & $\begin{array}{c}0.4484 \\
(0.0066)\end{array}$ & $\begin{array}{c}0.7699 \\
(0.0117)\end{array}$ & $\begin{array}{c}0.3576 \\
(0.2444)\end{array}$ & $\begin{array}{c}1.6769 \\
(0.0303)\end{array}$ & $\begin{array}{c}0.1654 \\
(0.0000)\end{array}$ \\
\hline
\end{tabular}

Among the factors that affect the efficiency of the operation, the impact of deposit and loan ratio that measure the relative size and liquidity of credit assets of RCCs and provision coverage on the efficiency of RCCs is consistent, which means that strengthening the scale of assets and risk management and reducing the non-performing rate is an important means of improving the efficiency of each RCCs. In contrast, the expansion of asset size has the greatest impact on Xingtai RCCs, followed by Hengshui, Baoding, Chengde RCCs; Provision coverage rate / non-performing loan ratio of RCCs in Shijiazhuang and Cangzhou is larger than other cities, Which shows that the risk management ability of Shijiazhuang and Cangzhou RCCs is better, and the ability of risk compensation has a great impact on the improvement of operating efficiency. The liquidity management ability of
Qinhuangdao and Hengshui RCCs has a great influence on the efficiency improvement.

The impact of financial innovation on the efficiency of RCCs is not consistent with the non-interest income ratio. Baoding, Cangzhou, Handan and other seven cities of the RCCs financial innovation level has a positive impact on the efficiency of the promotion. The financial innovation of Baoding RCCs has the greatest impact on efficiency promotion. The non-interest income ratio of Hengshui, Langfang, Tangshan, Zhangjiakou and other four RCCs has a negative impact on operating efficiency, but the statistics are not significant. It indicates that the RCCs' financial innovation level is not high; its impact on efficiency is not obvious. So these RCCs should enhance the level of financial innovation in the future. 
For most RCCs, the proportion of agriculture-related loans has a positive effect on the efficiency, but it is not statistically significant. Only the coefficients of the proportion of agriculture-related loans in Tangshan, Xingtai and Hengshui are statistically significant .It indicates that increasing scale of agriculture-related loans can improve performance. This shows that the scale of loan growth affect the efficiency of RCCs, and it has little to do with the nature of loans. In fact, most of the loans of RCCs are agriculture-related loans. In 2014, for example, agriculture-related loans of 11 RCCs are more than $70 \%$, of which Chengde, Hengshui agriculturerelated loans as high as $99.41 \%$ and $96.08 \%$.

From the external environment, the local industrial structure and the degree of economic development have a significant impact on the performance of RCCs. Reducing the proportion of agricultural output in GDP is conducive to improving RCCs' operational efficiency. But there are exceptions. The coefficient of agricultural production value in Cangzhou, Hengshui and Zhangjiakou is positive respectively, indicating the three regions' RCCs' business efficiency heavily rely on the degree of local agricultural development. The coefficient of per capita GDP is positive and is statistically significant, which means more developed economy make the higher efficiency of RCCs.

\section{CONCLUSION}

Although efficiency loss still exists in RCCs on the whole since the reform of RCCs in 2005, which is not a fullyefficient state, RCCs' business efficiency is in the continuous improvement. From the city point, operating efficiency of RCCs of most cities has a certain degree of rise, and has reached the DEA-effective state. However some cities' RCCs operating efficiency has declined since 2013. The efficiency loss is mainly due to the lower efficiency of pure technology, indicating that the management level is not high, lower scale efficiency is another important reason. Malmquist dynamic analysis shows that the efficiency improvement of RCCs since 2010 is mainly due to technological progress and technological innovation. Tobit model analysis shows that the relative size of credit assets, risk control ability and financial innovation level have a significant effect on the comprehensive efficiency of RCCs. External economic environment also influences the efficiency of RCCs. Higher efficiency of RCCs also results from developed economy and the lower proportion of agricultural output.
According to the conclusions, we get the following suggestions: first, RCCs should make the rational choice of scale based on their own economic development needs. To increase assets in the stage of increasing returns to scale is rational. For the excessive pursuit of scale expansion mode, the regulatory authorities should supervise and guide, so that the RCCs to achieve healthy development. Second, from the point of view of pure technical efficiency, it is necessary to strengthen internal management, enhance the ability to control risk, reduce business costs, and improve the quality of loans. Third, the empirical analysis shows that one of the important factors that restrict the efficiency of the RCCs is the backward technology innovation. Therefore, RCCs should strengthen financial innovation to improve the financial service ability for the rural regions. The banking cards business, internet banking services should be as a breakthrough to increase the proportion of non-interest income and optimize income structure. Fourth, because the external environment, which cannot be controlled by these managers, has obvious influence on the operating efficiency of RCCs, the regulatory authorities should consider the influence of external environment on the efficiency of the difference during evaluating these manager's performance, which is conducive to mobilize the enthusiasm of managers to strengthen internal management.

\section{REFERENCES}

[1] YUAN Yunfeng."Research on Banking Efficiency Based on Multi stage Super Efficiency DEA Model [J]."Journal of Central University of Finance and Economics, 2006(06):45-56. (In Chinese)

[2] ZHENG Guiting,Qi Shutian ."Analysis of the Economies of Scale and Financial Reform in China's Commercial Banks [J]."Economic Research, 2006, (10):25-27. (In Chinese)

[3] ZHAO Xiang."Analysis on the Efficiency of Bank Branch andIts Influencing Factors [J]."Economic Science, 2010(01):86-95. (In Chinese)

[4] LI Mingdi."An Empirical Study on the Efficiency of China's Urban Commercial Banks Based on DEA Method [J]."Shanghai Finance, 2015(12):106-108. (In Chinese)

[5] XIE Ping,XU Zhong."Performance Evaluation of Rural Credit Cooperative Reform [J]."Financial Research, 2006(01):23-29. (In Chinese)

[6] LAN Hong."Performance Evaluation and Promotion of Rural Credit Cooperatives in China after Reform [J]."Financial Research, 2014(04):63-81. (In Chinese)

[7] WANG Xiaoning."Analysis on Financing Efficiency of Small and Medium - sized Enterprises Based on Three - stage DEA Model [J]."Statistics and Decision, 2016(05); 179-182. (In Chinese)

[8] WU Shaoxin,LI Jianhua."Study on the Management Efficiency of Villages and Towns Based on DEA Super Efficiency Model [J]."Financial and Economic, 2009(12):45-49. (In Chinese) 